\title{
BODY MASS AND DYNAMICS OF GROWTH OF BROILER CHICKENS OF DIFFERENT GENOTYPE IN IMPROVED REARING CONDITONS **
}

\author{
Z. Škrbić ${ }^{1 *}$ Z. Pavlovski ${ }^{1}$, M. Lukić ${ }^{1}$ \\ ${ }^{1}$ Institute for Animal Husbandry, Belgrade-Zemun, Serbia \\ *Corresponding author: zdenkaskrbic@gmail.com \\ ** Original scientific paper. Research financed by the Ministry of Science of Republic of \\ Serbia, Project TR6885
}

\begin{abstract}
Application of lower housing density and discontinuous light programme, which at the same time marked the application of moderate photoperiod, had positive effect on realized final body masses of broiler chickens of both investigated genotype, however, exhibited effect was higher in chickens of Cobb genotype, considering that significantly greater body mass was established.

Chicken genotype is confirmed as important interactive factor in improved rearing conditions, considering higher average daily gains of Cobb chickens compared to Arbor Acres, also in all weekly investigations.
\end{abstract}

Key words: broilers, genotype, housing density, light programme

\section{Introduction and literature review}

Intensifying of broiler production in the last several decades was conditioned by progress in selection activities, creating of genotypes which would enable higher gains in shorter period of time. Of course, selection progress in broiler production was followed by optimalization of rearing conditions, nutrition and care of broiler chickens.

Growth of body mass is results of the effect of great number of factors and interactions occurring between those factors. Considering the importance of body mass, great changes in broiler production have occurred relating to body mass growth rate (Hopić et al., 1996). Statistically significant differences in body mass of chickens of different genotype were concluded by many authors (Hopić et al., 1993a,b; Vračar et al., 1996; Vračar et al., 1997; Ristić 1995; Havenstein et al., (2003). In order to 
compare the dynamics of growth of broiler chickens of different genotype, Židov (1991), based on the growth curve, concluded that realized differences in average body masses were consequence of different origin of broiler chickens and statistically highly significant in all weekly measurings/weighings.

Housing density is considered as one of the most important environment factors because of established impact on broiler chickens growth rate. Except this direct influence, housing density indirectly affects creation of microclimate in the chicken coop and forming of other environment factors. The following authors have indicated the increase of average body mass of chickens at the end of fattening with the decrease of housing density Lewis et al. (1997), Edriss et al. (2003), Mortari et al. (2004), Mendes et al. (2004), Çiçek et al. (2004), as well as dependence of exhibited differences in body masses when different housing densities were applied on fattening cycles (Edriss et al., 2003; Mortari et al., 2004; Dozier et al., 2005; 2006).

Results of previous research relating to application of light programmes, i.e. discontinuous light in broiler production indicate the possibility for improvement of production performances, fewer health problems and more rational production (Milošević et al., 1999). In Denmark, according to Petersen (2004), broilers can not be in continuous light and need to have at least 8 hours of dark period during day, although in future this period shall be reduced to 3 hours. In most of the studies presented by Buyse et al. (1996), increase in final body mass of broilers exposed to consecutive light was established. However, the importance of the chicken age is stressed, when body masses achieved in different light programmes were compared due to depression effect on initial growth of broiler chickens when continuous light programme was substituted with discontinuous. Ability to manifest compensatory growth depends on genotype (Cherry et al., 1978a). Cave et al. (1985) also stated that all broiler genotypes do not react identically to consecutive light and therefore light $\mathrm{x}$ genotype interaction is significant.

Investigation was carried out with objective to determine the effect of improved rearing systems in regard to application of lower housing density and discontinuous light programme which at the same time marked the application of moderate photo period, on final body mass and dynamics of growth of broiler chickens of different genotype.

\section{Material and methods}

Experimental research was carried out on 1709 broiler chickens of two 
genotypes (G), Cobb 500 and Arbor Acres. Chickens were distributed in boxes and reared on deep litter in two housing densities (GN): 16 and 12 birds $/ \mathrm{m}^{2}$ of floor surface to age of 42 days. Housing density of $16 \mathrm{birds} / \mathrm{m}^{2}$ of floor surface is technologically common in our climate and therefore can be considered as control in relation to density of $12 \mathrm{birds} / \mathrm{m}^{2}$ of floor surface. All chickens had adequate and same space for feeding and watering. This excludes the effect of other factors which could diminish the expression of the effect of investigated treatments. Applied light programmes included continuous (K), and discontinuous light (intermittent light - IL). Continuous light programme was 23L:1D. Discontinuous light programme was cyclic alteration $4 \mathrm{~L}: 2 \mathrm{D}$, i.e. total duration of photo period of 16 hours. Adequate light programmes were applied from 8 days of age, considering that in first days of life chickens need light as source of warmth because of their insufficient thermoregulation system. In order to monitor the dynamics of growth of broiler chickens, in weekly intervals control measuring of body mass of marked chickens was carried out. Based on differences in body mass of chickens determined in weekly measurings, weekly gain, as well as daily gain individually for each bird was calculated.

Obtained data base was analyzed using computer programme Stat.Soft, Inc. (2003) STATISTICA (data analysis software system), version 6.

\section{Results and Discussion}

Broiler chickens of Cobb genotype in discontinuous/intermittent light programme had significantly greater body masses compared to continuous, and final body masses of Arbor Acres broiler chickens weren't under influence of applied light programmes, which confirms the results of Cave et al. (1985) who stated that all genotypes of broiler chickens do not react in the same way on intermittent light. In regard to housing density, broiler chickens of both genotypes had significantly greater body masses in lower housing density, but chickens of Cobb genotype had considerably greater body masses compared to Arbor Acres genotype. Significantly greater body masses with lower housing density of broiler chickens were established by numerous authors (Bilgili and Hes 1995, Lewis et al. 1997, Mortari et al. 2002, Çiçek et al. 2004, Dozier et al. 2005). However, expression of differences in body mass of broiler chickens depends also on applied housing densities (Edriss et al., 2003). Also, application of lower housing density and discontinuous/intermittent light had positive effect on final body masses of broiler chickens of both investigated genotypes, but expressed 
effect was higher in chickens of Cobb genotype, considering established considerably greater body mass.

Table 1. Average body mass of chickens at the age of 42 days

\begin{tabular}{|c|c|c|c|c|c|}
\hline \multirow{2}{*}{\multicolumn{3}{|c|}{ Treatments }} & \multirow{3}{*}{$\begin{array}{c}n \\
434\end{array}$} & \multicolumn{2}{|c|}{ Body mass, g } \\
\hline & & & & \multirow{2}{*}{$\frac{\bar{x}}{2157.93^{b}}$} & \multirow{2}{*}{$\frac{\mathrm{Sd}}{266.71}$} \\
\hline \multirow{2}{*}{ Arbor Acres } & K & & & & \\
\hline & IL & & 423 & $2149.76^{b}$ & 270.83 \\
\hline \multirow{2}{*}{ Cobb } & $\mathrm{K}$ & & 409 & $2101.10^{c}$ & 288.72 \\
\hline & IL & & 420 & $2248.29^{\mathrm{a}}$ & 270.70 \\
\hline \multirow{2}{*}{ Arbor Acres } & & 12 & 364 & $2217.20^{\mathrm{b}}$ & 273.32 \\
\hline & & 16 & 493 & $2107.16^{\mathrm{c}}$ & 255.49 \\
\hline \multirow{2}{*}{ Cobb } & & 12 & 355 & $2271.44^{\mathrm{a}}$ & 276.60 \\
\hline & & 16 & 474 & $2103.95^{\mathrm{c}}$ & 277.51 \\
\hline \multirow{4}{*}{ Arbor Acres } & \multirow{2}{*}{ K } & 12 & 184 & $2198.48^{\mathrm{bc}}$ & 272.67 \\
\hline & & 16 & 250 & $2128.08^{\text {cde }}$ & 258.73 \\
\hline & \multirow{2}{*}{ IL } & 12 & 180 & $2236.33^{b}$ & 273.40 \\
\hline & & 16 & 243 & $2085.64^{\mathrm{e}}$ & 250.83 \\
\hline \multirow{4}{*}{ Cobb } & \multirow{2}{*}{ K } & 12 & 180 & $2206.06^{\mathrm{bd}}$ & 269.96 \\
\hline & & 16 & 229 & $2018.60^{\mathrm{e}}$ & 276.45 \\
\hline & \multirow{2}{*}{ IL } & 12 & 175 & $2338.69^{a}$ & 267.79 \\
\hline & & 16 & 245 & $2183.71^{\mathrm{bd}}$ & 254.27 \\
\hline
\end{tabular}

a-e different letters in columns indicate statistically significant differences at the level of $5 \%$

\section{Graph 1. Growth curve of broiler chickens of different genotypes}

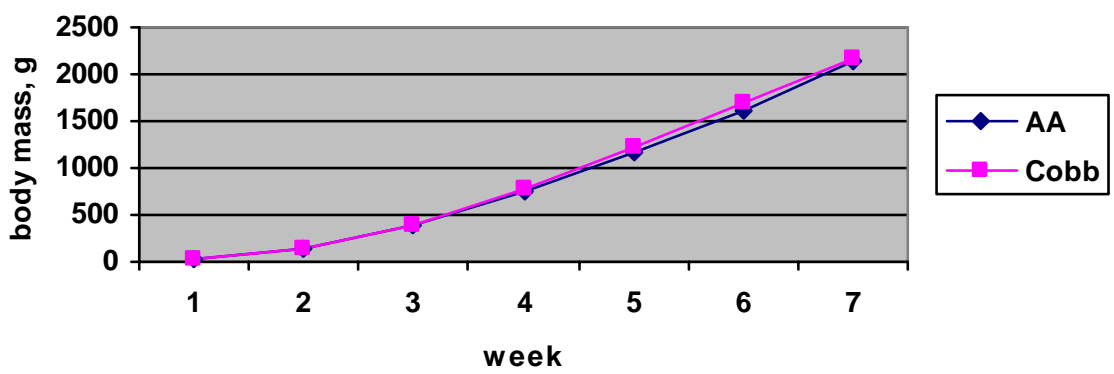

In accordance with results obtained by Schreiweis et al. (2003) presented growth curves (graph 1) indicate different growth dynamics of broiler chickens of different genotypes, or more intensive growth of Cobb chickens which reached the maximal values of average daily gains in the fifth week of age $(67.40 \mathrm{~g})$ and than a tendency of decrease can be observed, contrary to 
chickens of Arbor acres genotype which had continuous growth, so the highest daily gain was achieved in the last, sixth week of age $(75.60 \mathrm{~g})$. Absence of coincidence with results of certain authors (Židov 1991; Hopić et al., 1996) is probably consequence of differences in selection programmes of investigated genotypes of broiler chickens. In spite of established differences in growth dynamics, final body masses of Cobb and Arbor Acres chickens weren't statistically significant (2175.67 and $2153.90 \mathrm{~g}$ ).

Expression of significant effect of housing density on average daily gain of broiler chickens was concluded in first weeks of age (graph 2) which deviates from results obtained by Cravener et al. (1992) and Edriss et al. (2003) who stated the important effect of housing density on body mass in older chickens.

Graph 2. Growth curve of broiler chickens under the effect of applied housing density

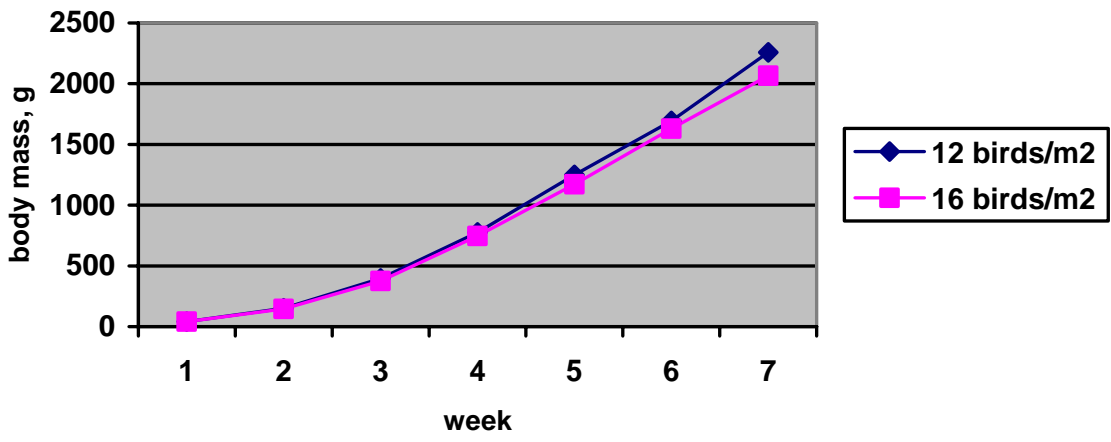

Explanation is probably that in easier access to food but also influence of season, considering that trial was carried out in summer period (with high environmental temperatures), which is in accordance with results by Mendesa et al. (2004) who established different optimal housing densities of broiler chickens depending on the season. Similar dependences are stated in research of Elwinger (1995) and Galobart and Moran (2005).

Realization of considerably greater body masses in broiler chickens with application of intermittent light programme is in accordance with results of previous research of most of the authors presented by Milošević et al. (1999). However, transition from continuous to discontinuous light programme changes the growth curve in broiler chickens, expressing first the depression effect on initial growth followed by compensatory growth (Buyse 
et al., 1994a; 1996; Özkan et al., 2006). Based on growth of body mass in weekly intervals (graph 3 ) it can be concluded that contrary to stated results, in this research, discontinuous light programme showed no depressive effect on initial growth of body mass of chickens, which is result of established interactions between light programme and other investigated factors whose significance of effect on gains of broiler chickens was confirmed.

Graph 3. Growth curve of broiler chickens under the effect of applied light programme

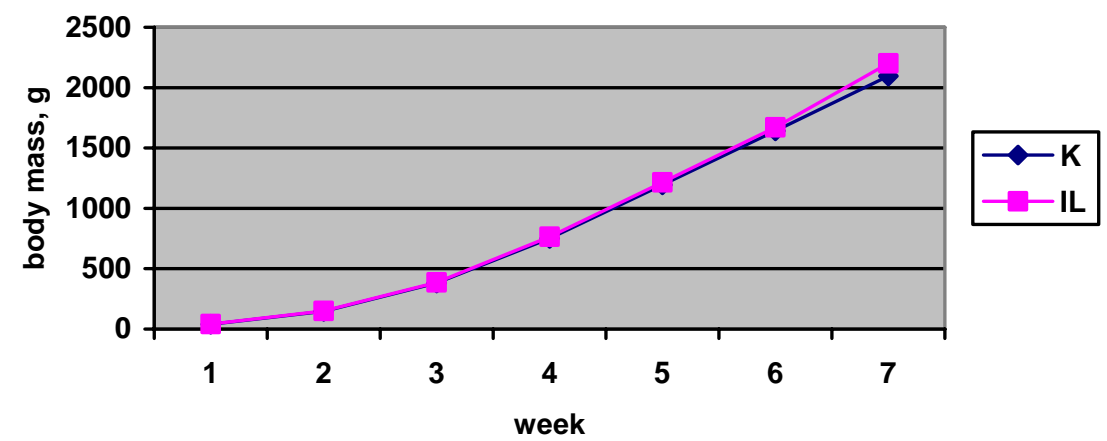

Interaction effect of genotype, light programme and housing density on average daily gains of chickens in weekly intervals is presented in table 2 .

Table 2. Average daily gain (g) of broiler chickens in weekly intervals

\begin{tabular}{|c|c|c|c|c|c|c|c|c|c|}
\hline \multirow{3}{*}{\multicolumn{2}{|c|}{$\begin{array}{c}\text { Age, } \\
\text { weeks }\end{array}$}} & \multicolumn{4}{|c|}{ Arbor Acres } & \multicolumn{4}{|c|}{ Cobb } \\
\hline & & \multicolumn{2}{|c|}{$\mathrm{K}$} & \multicolumn{2}{|c|}{ IL } & \multicolumn{2}{|c|}{$\mathrm{K}$} & \multicolumn{2}{|c|}{ IL } \\
\hline & & 12 & 16 & 12 & 16 & 12 & 16 & 12 & 16 \\
\hline \multicolumn{2}{|c|}{$\mathrm{n}$} & 92 & 125 & 91 & 118 & 89 & 116 & 84 & 122 \\
\hline \multirow{2}{*}{2.} & $x$ & $35.12^{\mathrm{ab}}$ & $33.35^{\mathrm{bc}}$ & $35.12^{\mathrm{ab}}$ & $30.51^{\mathrm{d}}$ & $34.57^{\mathrm{abc}}$ & $32.57^{\mathrm{c}}$ & $35.80^{\mathrm{a}}$ & $34.55^{\mathrm{ab}}$ \\
\hline & $\mathrm{Sd}$ & 4.96 & 4.50 & 4.76 & 4.25 & 4.35 & 4.15 & 5.28 & 4.74 \\
\hline \multirow{2}{*}{3.} & $\bar{x}$ & $53.05^{\mathrm{ab}}$ & $50.81^{b}$ & $54.98^{\mathrm{a}}$ & $53.89^{\mathrm{ab}}$ & $52.99^{\mathrm{ab}}$ & $54.50^{\mathrm{a}}$ & $55.06^{\mathrm{a}}$ & $52.80^{\mathrm{ab}}$ \\
\hline & $\mathrm{Sd}$ & 7.64 & 8.41 & 8.18 & 8.83 & 7.89 & 8.34 & 7.78 & 8.71 \\
\hline \multirow{2}{*}{4.} & $x$ & $64.91^{\mathrm{abc}}$ & $59.71^{\mathrm{c}}$ & $69.48^{\mathrm{a}}$ & $53.33^{\mathrm{d}}$ & $66.93^{\mathrm{ab}}$ & $63.07^{b c}$ & $69.37^{\mathrm{a}}$ & $67.62^{\mathrm{ab}}$ \\
\hline & $\mathrm{Sd}$ & 12.21 & 13.09 & 13.96 & 12.62 & 10.94 & 14.36 & 12.18 & 12.62 \\
\hline \multirow{2}{*}{5.} & $x$ & $60.37^{\mathrm{cd}}$ & $64.24^{\mathrm{bcd}}$ & $58.19^{\mathrm{d}}$ & $63.43^{\mathrm{bcd}}$ & $68.96^{\mathrm{ab}}$ & $62.56^{\text {bcd }}$ & $67.70^{\mathrm{abc}}$ & $70.67^{\mathrm{a}}$ \\
\hline & $\mathrm{Sd}$ & 14.92 & 16.29 & 19.31 & 15.74 & 17.64 & 13.38 & 12.88 & 14.79 \\
\hline \multirow{2}{*}{6.} & $x$ & $80.05^{\mathrm{ab}}$ & $74.24^{\mathrm{bc}}$ & $80.28^{\mathrm{ab}}$ & $69.95^{\mathrm{c}}$ & $75.57^{\mathrm{bc}}$ & $34.22^{\mathrm{d}}$ & $86.28^{\mathrm{a}}$ & $69.98^{\mathrm{c}}$ \\
\hline & $\mathrm{Sd}$ & 14.22 & 25.43 & 15.03 & 20.03 & 14.72 & 18.63 & 15.39 & 18.02 \\
\hline
\end{tabular}

a-d different letters within rows indicate statistically significant differences at the level of 
Data presented in table indicate realized average daily gains of chickens of both genotypes in lower housing density and discontinuous light programme compared to higher housing density and continuous light programme. Also, genotype of chickens was confirmed as interactive factor, considering established greater average daily gains of Cobb chickens in improved rearing conditions in all weekly investigations compared to Arbor Acres, although statistical significance of stated differences was confirmed only in the fifth investigation week.

\title{
Conclusion
}

- Application of discontinuous/intermittent light programme expressed positive effect on final body masses of broiler chickens of Cobb genotype, whereas such effect wasn't present in Arbor Acres chickens.

- Rearing of chickens of both genotypes in lower housing density had effect on significant increase of final body masses.

- Average daily gains of broiler chickens in weekly investigations indicated different dynamics of growth where chickens of Cobb genotype finished earlier their maximal growth compared to Arbor Acres chickens. More intensive growth was registered in chickens reared in lower than in higher housing density. Application of discontinuous light programme caused no manifestation of depressed growth in first weekly investigations of body mass gain.

- Improved rearing conditions, in regard to application of lower housing density and discontinuous light programme, provide higher daily gains of body masses of chickens of both investigated genotypes, but with more expressed effect on gain of body masses of Cobb chickens.

\section{TELESNA MASA I DINAMIKA PORASTA BROJLERSKIH PILIĆA RAZLIČITOG GENOTIPA U POBOLJŠANIM USLOVIMA GAJENJA}

\author{
Z. Škrbić, Z. Pavlovski, M. Lukić
}




\section{Rezime}

Primena manje gustine naseljenosti i diskontinuiniranog svetlosnog programa, koji je istovremeno označavao i primenu umerenog fotoperioda, je imala pozitivan efekat na ostvarene završne telesne mase brojlerskih pilića oba ispitivana genotipa, s tim da je ispoljeni uticaj bio veći kod pilića genotipa Cobb, obzirom na utvrđenu značajno veću telesnu masu.

Genotip pilića je potvrđen kao važan interaktivni faktor u poboljšanim uslovima gajenja, obzirom na utvrđene veće prosečne dnevne priraste pilića genotipa Cobb u odnosu na Arbor Acres, takođe u svim nedeljnim ispitivanjima.

\section{References}

BILGILI S.F., HESS J.B. (1995): Placement density influences broiler carcass grade and meat yields. Journal of Applied Poultry Research, 4: 384389.

BUYSE J., ADELSOHN D.S., DECUYPERE E., SCANES C.G. (1994a): Intermittent lighting and broiler production. 1. Effect on female broiler performance. Archiv für Geflugelkunde 58, 69-74.

BUYSE J., SIMONS P.C.M., BOSHOUWERS E.M.G., DECUYPERE E. (1996): Effect of intermittent lighting, light intensity and source on the performance and welfare of broilers. World's Poultry Science Journal, Vol. 52 (2), 121-130.

CAVE N.A., BENTLEY A.H., MACLEAN H. (1985): The effect of intermittent lighting on growth, feed: gain ratio, and abdominal fat content of broilers of various genotypes and sex. Poultry Science 64, 447-453.

CHERRY J.A., BEANE W.L., WEAVER JR., W.D. (1978A): The influence of dietary energy on the performance of broilers reared under different lighting regimes. Poultry Science 57, 998-1001.

ÇIÇEK T., KILIÇ S., ÇALIŞLAR S., KARAMAN M., GÜRBÜZ Y. (2004): Effects of cage and floor housing in different stocking densities on performance and some carcass characteristics of japanese quails. XXII World's Poultry Congress, Istanbul-Turkey, 8-13 June 2004, Book of abstracts, 423.

CRAVENER T.L., ROUSH W.B., MASHALY M.M. (1992): Broiler production under varying population densities. Poultry Science, 71, 427-433. DOZIER W.A., THAXTON J.P., BRANTON S.L., MORGAN G.W., MILES D.M., ROUSH W.B., LOTT B.D., VIZZIER-THAXTON Y. (2005): 
Stocking Density on Growth Performance and Processing Yields of Heavy Broilers. Poultry Science 84: 1332-1338.

DOZIER W.A., THAXTON J.P., PURSWELL J.L., OLANREWAJU H.A., BRANTON S.L., ROUSH W. B. (2006): Stocking Density Effects on Male Broilers Grown to 1,8 Kilograms of Body Weight. Poultry Science 85: 344351.

EDRISS M.A., DAVOODVANDI S., POURREZA J. (2003): The Effect of stock density on the predoction of performance and carcass traits in broiler chickens. Proceedings XVI ${ }^{\text {th }}$ European Symposium on the Quality of Poultry Meat, September 2003., Saint-Brienc, France, 695-700.

ELWINGER K. (1995): Broiler production under varying population densities-A field study. Archiv für Geflügelkunde, 59 (4), 209-215.

GALOBART J., MORAN E.T. (2005): Influence of Stcking Density and Feed Pellet Quality on Heat Stressed Broilers from 6 to 8 Weeks of Age. International Journal of Poultry Science, 4(2), 55-59.

HAVENSTEIN G.B., FERKET P.R., QURESHI M.A. (2003): Growth, Livability and Feed Conversion of 1957 Versus 2001 Broilers When Fed Representative 1957 and 2001 Broiler Diets. Poultry Science, 82: 15001508.

HOPIĆ S., PAVLOVSKI Z., CMILJANIĆ R., MAŠIĆ B., VRAČAR S. (1996): Nedeljni rast telesne mase brojlerskih pilića različitog genotipa i pola. Nauka u živinarstvu 1 (3-4), 131-141.

HOPIĆ S., PAVLOVSKI Z., MAŠIĆ B. (1993): Uporedno ispitivanje proizvodnih osobina brojlera različitih provenijenci 1991.godine. Biotehnologija u stočarstvu, 3-4, 25-33.

HOPIĆ S., PAVLOVSKI Z., MAŠIĆ B. (1993): Uporedno ispitivanje proizvodnih osobina brojlera različitih provenijenci 1992.godine. Simpozijum povodom 90 godina života i rada prof. dr Dragiše Nikolića. Zbornik radova Poljoprivrednog fakulteta, 129-135.

LEWIS P.D., PERRY G.C., FARMER L.J., PATTERSON R.L.S. (1997): Responses of Two Genotypes of Chicken to the Diets and Stocking Densities Typical of UK and "Label Rouge" Production Systems: 1. Performance, Behaviour and Carcass Composition. Meat Science, Vol. 45, No. 4, 501-516. MENDES A.A., GARCIA R.G., IMEIDA I.C.L.A., MOREIRA J. (2004): Effect of stocking densities and season on performance, environmental and thermoregulatory parameters and carcass yield of broiler chickens. XXII World's Poultry Congress, Istanbul-Turkey, 8-13 June 2004, Book of abstracts, 417.

MILOŠEVIĆ N., PERIĆ L., SUPIĆ B., PAVLOVSKI Z. (1999): Primena 
različitih svetlosnih režima u tovu brojlerskih pilića. Živinarstvo, 5, 30-39. MORTARI A.C., ROSA A.P., ZANELLA I., NETO C.B., VISENTIN P.R., BRITES L.B.P. (2002): Performance of broilers reared in different population density, in winter, in South Brazil. Ciência Rural 32(3). ÖZKAN S., YALCIN S., ABBAS Y., KIRKPINAR F., GEVREKCI Y., TÜRKMUT L. (2006): Effects of short day (16L:8D) lenght on broilers: some physiological and welfare indicies. XII European Conference, Verona, Italy. World's Poultry Science Journal. Book of abstracts, 62, 584.

PETERSON J.S. (2004): Management and housing systems for broilers Effects on welfare and production. XXII World's Poultry Congress, Istanbul-Turkey, 8-13 June 2004, Book of abstracts, 325.

RISTIĆ M. (1995): Fleischqualität von broilern verschiedener genotypen. IV međunarodni Simpozijum "Novi pravci razvoja stočarstva", Biotehnologija u stočarstvu, 11 (3-6), 273-278.

SCHREIWEIS M.A., ORBAN J.I., LEDUR M.C., HESTER P.Y. (2003): The use of densitometry to detect differences in bone mineral density and content of live White Leghorns fed varying levels of dietary calcium. Poultry Science, 82: 1292-1301.

VRAČAR S., PAVLOVSKI Z., HOPIĆ S., LUKIĆ M., ŠKRBIĆ Z. (1997): Uticaj genotipa na proizvodne i klanične karakteristike brojlerskih pilića. Nauka u živinarstvu, 2 (3-4), 135-141.

VRAČAR S., PAVLOVSKI Z.,HOPIĆ S., LUKIĆ M., ŠKRBIĆ Z. (1996): Uporedno ispitivanje proizvodnih osobina brojlerskih pilića različirih genotipova. Nauka u živinarstvu, 1 (3-4), 141-149.

ŽIDOV N. (1991): Uporedna analiza dinamike rasta pilića domaćih i inostranih brojlerskih hibrida. Zbornik radova "Živinarski denovi", Ohrid, sekcija I, 51-60. 